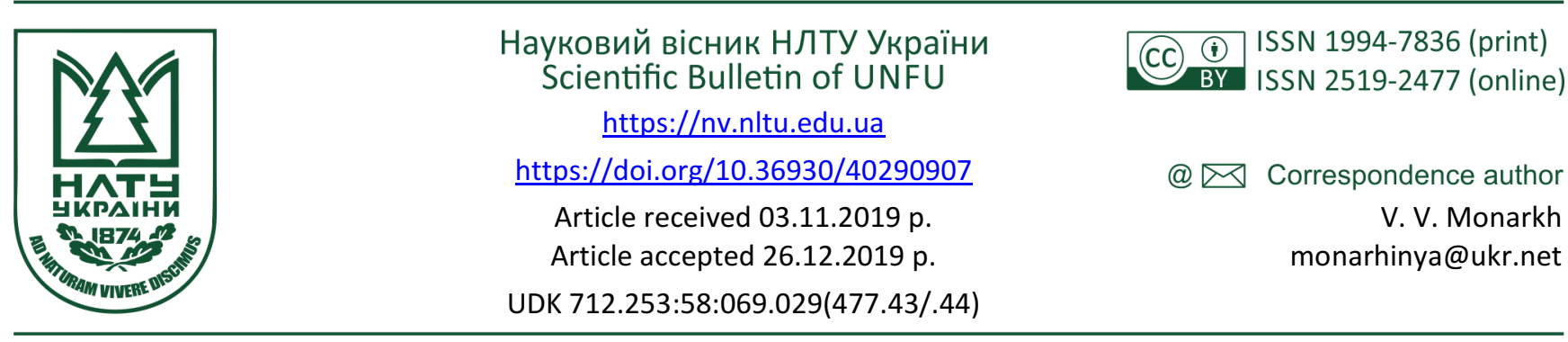

В. В. Монарх, В. В. Костенюк, А. В. Королишина

Вінницький національний аграрний університет, м. Вінниия, Украӥна

\title{
ПЕРСПЕКТИВНІСТЬ СТВОРЕННЯ ОБ'ЄКТІВ ДЕКОРАТИВНОГО ЗНАЧЕННЯ НА БАЗІ БОТАНІЧНОГО САДУ "ПОДІЛЛЯ"
}

\begin{abstract}
Описано роль та значення Ботанічного саду "Поділля", як парку-пам'ятки садово-паркового мистецтва загальнодержавного значення. Ботанічний сад "Поділля" є парком-пам'яткою садово-паркового мистецтва загальнодержавного значення і розкриває красу та неповторність Подільської дендрофлори. Поряд з великим різноманіттям наукових завдань Ботанічний сад є завершеним творінням садово-паркового будівництва, де важливу роль відіграє формування ландшафтних композиції, як окремих ділянок, так і усього саду загалом. Ландшафтні композиції саду розкривають найцікавіші природні компоненти довколишнього ландшафту, якнайкраще вирішують архітектурно-планувальні зв'язки на його території, а також висвітлюють декоративні і художньо-естетичні властивості рослин. Висвітлено основні періоди створення Ботанічного саду. Подано таксономічну структуру культивованої дендрофлори Ботанічного саду. Проведено аналіз розподілу території. До складу Ботанічного саду "Поділля" входять, такі відділи як: дендрарій; типологічний відділ лісів Поділля; помологічний відділ (плодово-ягідних культур); систематичний відділ трав'яних рослин; відділ декоративних культур; розсадник декоративних і диких плодово-ягідних культур; відділ природознавства і охорони природи; зимовий сад з колекцією унікальних для Поділля субтропічних рослин. Окрім основних композиційних центрів, таких як ставок, центральна алея, паркові площі, партери і поляни, що розташовані по основному маршруту, в Ботанічному саду виділяють ще такі об'єкти декоративного та утилітарного характеру, як: розарій, сирінгарій, дендрарій, науково-дослідні ділянки факультету агрономії та лісівництва, теплиці, плодовий розсадник, біостаціонар, оранжерея та експозиційна ділянка квітниково-декоративних рослин. Висвітлено перспективність використання об'єктів декоративного та утилітарного значення для збереження та збагачення рослинного різноманіття. Описано важливість та потреба знайомства студентів з деревно-чагарниковими, квітниково-декоративними угрупованнями на базі Ботанічного саду для отримання потрібних практичних вмінь і навиків.
\end{abstract}

Ключові слова: інтродуцент; біостаціонар; аналіз; озеленення; парк-пам'ятка.

Вступ. Ботанічними садами називають культурнопросвітницькі та науково-дослідні заклади, в яких накопичують колекції флори для іiі вивчення, збереження, культивування та акліматизації. Ботанічні сади $\epsilon$ об'єктами збереження біорізноманіття, в яких постійно відбувається пошук і добір рослин, перспективних для створення зелених насаджень і здійснення інших видів господарської діяльності (Monarkh, 2019).

Одним із об'єктів зеленого кільця міста Вінниці є Ботанічний сад "Поділля", який розташований на території Вінницького національного аграрного університету (ВНАУ). Ботанічний сад - це науково-методична база для проведення прикладних досліджень студентами i науковцями університету в галузях квітникарства, декоративного садівництва, лісівництва, лісомеліорації, фізіології рослин, екології тощо.

Поряд з тим, Ботанічний сад $є$ базою для розроблення обласних регіональних програм з озеленення території, вивчення еколандшафтів Поділля, моніторингу рід- кісних рослин, що зникають. Наявність такого об'єкта у структурі університету дає змогу підтримувати тісний зв'язок із заповідними зонами Вінницької області та Ботанічними садами України, здійснювати науковопрактичну співпрацю з обласною станцією садівництва, Інститутом садівництва НААН та іншими установами (Botanichnyi sad, 2019).

Аналіз останніх публікацій. Ботанічний сад було створено за рішенням Вінницької обласної Ради від 20 серпня 1965 р. як науковий центр з вивчення різноманітних питань 3 ботаніки, рослинництва, плодоовочівництва, декоративного садівництва і квітникарства (Liubchak, 1990). Створено цей об'єкт на громадських засадах, за участю співробітників педінституту, технікумів, шкіл, лісівництва згідно 3 із схематичним планом. Фундаторами та людьми, які зробили неоціненний внесок у формування рослинних груп, підбір колекцій, будівництво і подальший розвиток Ботанічного саду стало подружжя Паламарчуків Галини Леонідівни та

\section{Інформація про авторів:}

Монарх Вероніка Валентинівна, канд. с.-г. наук, ст. викладач, кафедра садово-паркового господарства, садівництва та виноградарства. Email: monarhinya@ukr.net; https://orcid.org/0000-0002-4473-7683

Костенюк Валерія Валеріївна, магістрант, кафедра садово-паркового господарства, садівництва та виноградарства. Email: valeriia1997dark@gmail.com

Королишина Альона Валентинівна, магістрант, кафедра садово-паркового господарства, садівництва та виноградарства. Email: malesheva05@gmail.com

Цитування за ДстУ: Монарх В. В., Костенюк В. В., Королишина А. В. Перспективність створення об'єктів декоративного значення на базі Ботанічного саду "Поділля". Науковий вісник НЛтУ України. 2019, т. 29, № 9. С. 42-45.

Citation APA: Monarkh, V. V., Kostenyuk, V. V., \& Korolishina, A. V. (2019). Prospects for the establishment of the ornamental objects on the basis of Podillia Botanic Garden. Scientific Bulletin of UNFU, 29(9), 42-45. https://doi.org/10.36930/40290907 
Анатолія Семеновича. Оскільки Ботанічний сад передусім повинен був відтворювати багатство флори Поділля, то для висадки деревних і чагарникових порід було використано посадковий матеріал 3 розсадників і лісництв Вінницької обл. (Hudzevych, 2008).

Сьогодні Ботанічний сад "Поділля" $є$ парком-пам'яткою садово-паркового мистецтва загальнодержавного значення і розкриває красу й неповторність Подільської дендрофлори. Поряд 3 великим різноманіттям наукових завдань Ботанічний сад $є$ завершеним творінням садово-паркового будівництва, де важливу роль відіграє формування ландшафтних композиції, як окремих ділянок, так і усього саду загалом. Ландшафтні композиції саду розкривають найцікавіші природні компоненти довколишнього ландшафту, якнайкраще вирішують архітектурно-планувальні зв'язки на його території, а також висвітлюють декоративні і художньо-естетичні властивості рослин (Monarkh, 2019; Botanichnyi sad, 2019; Liubchak, 1990; Hudzevych, 2008).

Об'єкт дослідження - створення об'єктів декоративного значення.

Предмет дослідження - методи створення об'єктів декоративного значення на базі Ботанічного саду "Поділля".

Мета роботи - обгрунтувати важливість і перспективність створення, а надалі й використання об'єктів декоративного та утилітарного значення на базі Ботанічного саду "Поділля" для отримання студентами практичних вмінь і навиків з обраної спеціальності.

Основні завдання дослідження - опрацювати архівні матеріали об'єкта, узагальнити композиційно-планувальні особливості об'єктів декоративного та утилітарного значення на базі Ботанічного саду "Поділля".

Результати та їх обговорення. До складу Ботанічного саду "Поділля" входять такі відділи, як: дендрарій; типологічний відділ лісів Поділля; помологічний відділ (плодово-ягідних культур); систематичний відділ трав'яних рослин; відділ декоративних культур; розсадник декоративних і диких плодово-ягідних культур; відділ природознавства і охорони природи; зимовий сад 3 колекцією унікальних для Поділля субтропічних рослин (Kokhno, Hordiienko \& Zakharenko, 2001).

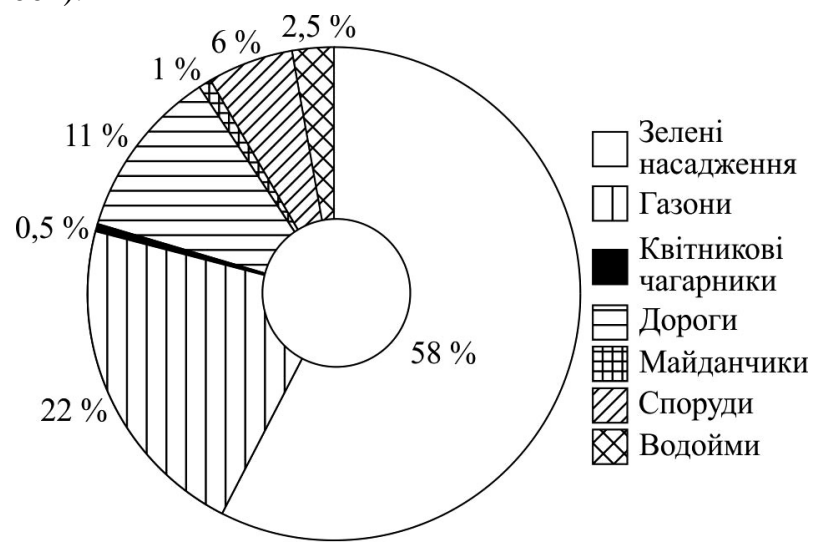

Рис. 1. Баланс території Ботанічного саду "Поділля"

Як видно 3 даних рис. 1, понад $58 \%$ території саду зайнято під деревно-чагарниковими насадженнями, решта $42 \%$ - площа відкритих просторів (газони, майданчики, водойми, дороги).

Окрім основних композиційних центрів, таких як ставок, центральна алея, паркові площі, партери і поля- ни, що розташовані по основному маршруту, в Ботанічному саду виділяють ще такі об'єкти декоративного та утилітарного характеру, як: розарій, сірінгарій, дендрарій, науково-дослідні ділянки факультету агрономії та лісівництва, теплиці, плодовий розсадник, біостаціонар, оранжерея та експозиційна ділянка квітниково-декоративних рослин.

Одним із сучасних об'єктів, який було закладено у 2015 р., є біостаціонар деревно-чагарникових рослин. На площі близько 0,35 га висаджено понад 100 видів деревно-кущових та більше 20 видів трав'яних рослин. Із них більше 25 сортів айстри китайської та біля 50 сортів троянди чайно-гібридної. На сьогодні на об'єкті біостаціонару розміщено колекційні особини дерев і чагарників у кількості 411 шт. Життєві форми рослин налічують: дерев $(21 \%)$ - 89 особин, кущів (79 \%) - 322 особини. У навчальному процесі розсадник є головним об'єктом для отримання практичних знань та проходження навчальної практики (Kokhno, Hordiienko \& Zakharenko, 2001; Matusiak, 2018). За таксономічною приналежністю колекційні рослини віднесено до 70 видових і внутрішньовидових таксонів, 36 родів, 18 родин. Серед них 123 особини - хвойні (відділ голонасінні), а 288 - листяні (відділ покритонасінні) (табл. 1) (Matusiak, 2018; Prokopchuk, Tsyhanskyi \& Tsyhanska, 2018)

У теплиці, що розташована на території Ботанічного саду, студенти університету, під час практичних занять та проходження практики, під керівництвом викладачів кафедри лісового, садово-паркового господарства, садівництва та виноградарства факультету агрономії та лісівництва здійснюють вирощування розсади малопоширених видів декоративних та овочевих культур, живцювання декоративних форм самшиту та інших хвойних рослин (Prokopchuk, Tsyhanskyi \& Tsyhanska, 2018).

Для вивчення, розмноження і реалізації посадкового матеріалу, постійно поповнюють та вдосконалюють плодово-ягідний розсадник, розташований на території Ботанічного саду. У розсаднику є колекції суниці садової, малини деревовидної і ремонтантної, винограду, ожини, смородини, а також є маточник клонових підщеп яблуні та груші.

Місцем закріплення теоретичних знань студентів спеціальності "Лісове господарство" $є$ Мисливський куточок, який було створено не так давно. На майбутнє тут планують розмістити стенди, що розповідають про біологію основних мисливських тварин України, основні види біотехнічних споруд, правила техніки безпеки під час полювання, 3 якими можуть ознайомитися не лише мисливці, а й інші відвідувачі лісу. Наразі в мисливському куточку є годівниця для тварин та підгодівельний майданчик.

У квітні 2017 р. на території Ботанічного саду було створено експозиційну ділянку квітниково-декоративних рослин. За своїм планом ділянка ділиться на партерну та частину квітниково-декоративних видів рослин. Партерна частина оформлена газоном з розміщеним у центрі логотипом ВНАУ, висадженого із бархатців однорічних. Облямівкою газону є живопліт із висадженої спіреї японської та бирючини звичайної, котрий підкреслює англійський класичний стиль переважаючих низькорослих регулярно стрижених трав газону. Частина квітниково-декоративних видів рослин, сфор- 
мована у вигляді орнаменту вишиванки, за проектом, який створили студенти спеціальності "Садово-паркове господарство". Центральними елементами цієї ландшафтної композиції є восьмигранні зірки, в які висаджено канну індійську та шавлію садову із яскраво-червоним забарвленням квітів. Окрім цього, барвистість кольорів доповнюють такі однорічні квітниково-деко- ративні види рослин, як: волошка лучна, бархатці махрові, цинія елегантна, левові ротики, калістефус китайський, мак каліфорнійський. Серед багаторічних рослин такі як: ірис бородатий, айстра багаторічна, лілії, жоржини та ін. (Mazur, Prokopchuk \& Pantsyreva, 2018; Cherniak, Prokopchuk \& Monarkh, 2018).

Табл. 1. Видовий асортимент рослин біостаціонару Ботанічного саду "Поділля"

\begin{tabular}{|c|c|c|c|}
\hline № $3 / \Pi$ & Назва родини & Назва роду & Кількість особин, шт. \\
\hline \multicolumn{4}{|c|}{ Відділ Голонасінні (PINOPHYTA) } \\
\hline \multirow{4}{*}{1} & Cupressaceae & Chamaecyparis Spach., Thuja L., Juniperus L. & 80 \\
\hline & Pinaceae & $\begin{array}{c}\text { Abies Mill., Pseudotsuga Carr., Tsuga Carr., Picea A. Dietr., Larix } \\
\text { Mill., Pinus L. }\end{array}$ & 26 \\
\hline & Ginkgoaceae & Ginkgo L. & 6 \\
\hline & Taxaceae & Taxus L. & 11 \\
\hline \multicolumn{4}{|c|}{ Відділ Покритонасінні (MAGNOLIOPHYTA) } \\
\hline \multirow{14}{*}{2} & Rosaceae & $\begin{array}{c}\text { Spiraea L., Physocarpus Maxim., Sorbaria A. Br., Rosa L., Cerasus } \\
\text { Juss., Aronia Med., Cotoneaster B. Ehrh. }\end{array}$ & 62 \\
\hline & Buxaceae & Buxus L. & 30 \\
\hline & Fagaceae & Fagus L., Castanea Mill., Quercsus L. & 5 \\
\hline & Hydrangaceae & Hydrangea L., Philadelphus L., Deutzia Thunb. & 15 \\
\hline & Oleaceae & Fraxinus L., Syringa L. Forsythia Vahl., Ligustrum L. & 25 \\
\hline & Celastraceae & Euonymus L. & 9 \\
\hline & Caprifoliaceae & Lonicera L., Weigela Thunb., Symphoricarpos L. & 5 \\
\hline & Fabaceae & Robinia L., Caragana Lam., Colutea L. & 1 \\
\hline & Berberidaceae & Berberis L., Mahonia Nutt. & 10 \\
\hline & Aceraceae & Acer $\mathrm{L}$. & 6 \\
\hline & Rhamnaceae & Rhamnus L., Frangula Mill. & 5 \\
\hline & Magnoliaceae & Magnolia L., Liriodendron L. & 9 \\
\hline & Bignoniaceae & Catalpa Scop., Campsis Lour. & 3 \\
\hline & Betulaceae & Betula L., Alnus Mill., Carpinus L., Corylus L. & 103 \\
\hline
\end{tabular}

Окрасою експозиційної ділянки є топіарні фігури (рис. 2) класичної (жива огорожа, спіраль) та каркасної техніки формування (слон, кактус, амфора). У планах поповнити експозиційну ділянку колекціями нових топіарів та створити цікаві ландшафтні композиції з використанням скульптури та елементів вертикального озеленення.

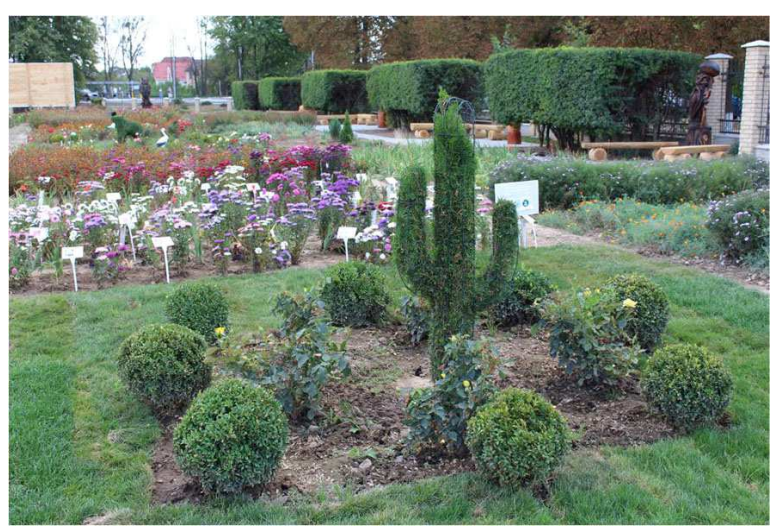

Рис. 2. Ландшафтні композиції із топіарів

Таксономічна структура культивованої дендрофлори Ботанічного саду (табл. 2) відображає внутрішню будову і специфічні особливості рослинних угруповань Ботанічного саду "Поділля". Важливим і досліджуваним показником $є$ кількість таксонів різного рангу. Основною ознакою пристосованості рослин до нових екологічних факторів є певна життєва форма рослин. Використання рослин певного біологічного типу відіграє важливу роль у створенні композиційних паркових ландшафтів (Serebriakov, 1952).

Табл. 2. Біоморфологічна структура культивованої дендрофлори Ботанічного саду "Поділля"

\begin{tabular}{|c|c|c|c|c|}
\hline \multirow{2}{*}{$\begin{array}{c}\text { № } \\
\text { 3/ח }\end{array}$} & \multirow{2}{*}{ Назва родини } & \multicolumn{3}{|c|}{ Життєва форма } \\
\hline & & дерево & кущ & ліана \\
\hline \multicolumn{5}{|c|}{ Відділ Голонасінні - Pinophyta } \\
\hline 1 & Соснові - Pinaceae & 7 & - & 1 \\
\hline 2 & Кипарисові-Cupressaceae & 3 & - & - \\
\hline 3 & Тисові - Tахасеае & 1 & - & - \\
\hline 4 & Гінкгові - Ginkgoaceae & 1 & - & - \\
\hline \multicolumn{5}{|c|}{ Відділ Покритонасінні - Magnoliophyta } \\
\hline 5 & Адоксові-Adoxaceae & 3 & - & 6 \\
\hline 6 & Аралієві - Araliaceae & - & - & 1 \\
\hline 7 & Березові-Betulaceae & 9 & - & - \\
\hline 8 & Бобові -Fabaceae & 6 & 3 & - \\
\hline 9 & Букові - Fagaceae & 7 & - & - \\
\hline 10 & Барбарисові-Berberidaceae & - & 4 & - \\
\hline 11 & Бересклетові - Celastraceae & 1 & - & - \\
\hline 12 & Бігнонієві - Bignoniaceae & 1 & - & - \\
\hline 13 & Вербові Salicaceae & 3 & - & - \\
\hline 14 & Bересові - Ericaceae & - & 2 & - \\
\hline 15 & Виноградові - Vitaceae & - & - & 2 \\
\hline 16 & Горіхові-Juglandaceae & 2 & - & - \\
\hline 17 & Гортензієві - Hydrangeaceae & - & 5 & - \\
\hline 18 & Жимолостеві - Caprifoliaceae & - & 3 & - \\
\hline 19 & Жовтецеві - Ranunculaceae & - & - & 2 \\
\hline 20 & Липові - Tiliaceae & 2 & - & - \\
\hline 21 & Магнолієві - Magnoliaceae & 3 & - & - \\
\hline 22 & Маслинові - Oleaceae & 5 & - & - \\
\hline 23 & Платанові - Platanaceae & 1 & - & - \\
\hline 24 & Розові - Rosaceae & 9 & 18 & - \\
\hline 25 & Рутові - Rutaceae & 1 & - & - \\
\hline
\end{tabular}




\begin{tabular}{|c|l|c|c|c|}
\hline 26 & Самшитові - Buхасеае & - & 1 & - \\
\hline 27 & Сапіндові - Sapindaceae & 4 & - & - \\
\hline 28 & Шовковицеві - Moraceae & 1 & - & - \\
\hline \multicolumn{2}{|c|}{ Всього } & 70 & 36 & 12 \\
\hline
\end{tabular}

Серед життєвих форм (рис. 3) дендрофлори у Ботанічному саду "Поділля" переважають дерева$61 \%$, кущі - $34 \%$ та ліани - $5 \%$.

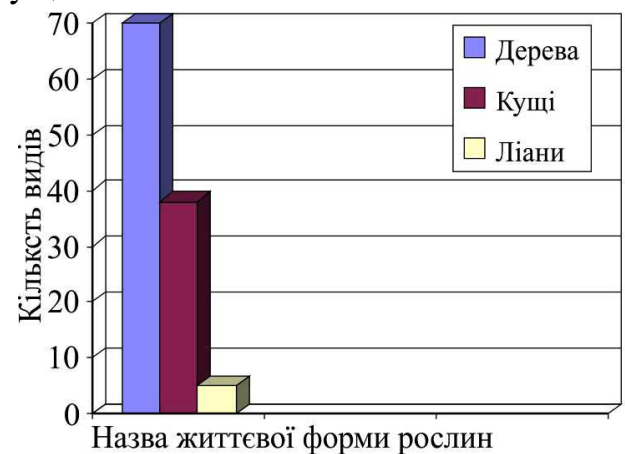

Рис. 3. Життєві форми дендрофлори Ботанічного саду "Поділля"

Під поняттям життєвої форми більшість авторів визначають пристосованість до відповідних умов росту. Повнішу класифікацію життєвих форм рослин описав I. Г. Серебряков, як своєрідну групу рослин, специфіка яких виражена в їх сезонному розвитку, способах щорічного наростання та відновлення, своєрідності декоративних якостей, які історично виникли в певних грунтово-кліматичних, фітоценотичних умовах, відтворюючи адаптацію рослин до цих умов (Serebriakov, 1952; Vulf, 1944; Popov, 1983).

Висновки. Сучасні об'єкти, що створені на території Ботанічного саду "Поділля", мають не тільки декоративний, а й утилітарний характер. Так, на експозиційній ділянці, теплиці, плодовому розсаднику, біостаціонарі чи мисливському куточку студенти під час навчальної і виробничої практики та практичних занять самостійно під керівництвом викладачів знайомляться з технологію вирощування, вивчають особливості росту та розвитку рослин, проводять догляд за ними та визначають можливості використання декоративних рослин в озелененні громадських об'єктів та приватних ділянок. Самос- тійна робота, на яку відводиться значна частина часу студентів, мотивує, активізує, формує та дає змогу студентам вчитися правильно приймати і реалізувати рішення відповідно до обраної професії.

\section{References}

Botanichnyi sad. (2019). Podilskyi Botanichnyi sad. Retrieved from: https://socrates.vsau.org/bg [In Ukrainian].

Cherniak, V. M., Prokopchuk, V. M., \& Monarkh, V. V. (2018). Some prospects of growing and use of China aster aor space greening in Podillia zone. Scientific Bulletin of UNFU, 28(7), 22-26. https://doi.org/10.15421/40280704

Hudzevych, A. (2008). Zapovidni kutochky Vinnytsi. Vinnytsia, pp. 14-19. [In Ukrainian].

Kokhno, M. A., Hordiienko, V. I., \& Zakharenko, H. S. (2001). Dendroflora Ukrainy: Dykorosli ta kultyvovani dereva y kushchi. Holonasinni. Kyiv: High school, 207 p. [In Ukrainian].

Liubchak, O. O. (1990). Charivne Podillia, (pp. 15-24). Odesa: Maiak. [In Ukrainian].

Matusiak, M. V. (2018). Bioloho-ekolohichni osoblyvosti vykorystannia vydiv rodu zhymolost (Lonicera L.) v umovakh biostatsionaru Vinnytskoho natsionalnoho ahrarnoho universytetu. Scientific Bulletin of UNFU, 28(10), 41-44. https://doi.org/10.15421/40281008

Mazur, V. A., Prokopchuk, V. M., \& Pantsyreva, H. V. (2018). Perspektyvnist stvorennia kolektsii pivonii na bazi Botanichnoho sadu "Podillia" Vinnytskoho natsionalnoho ahrarnoho universytetu. Silske hospodarstvo ta lisivnytstvo: zbirnyk naukovykh prats VNAU, 10, 5-18. [In Ukrainian].

Monarkh, V. V. (2019). Biological and ecological characteristics of dendroflora of Podillia Botanical garden of Vinnytsia national agrarian university. Silske hospodarstvo ta lisivnytstvo: zbirnyk naukovykh prats VNAU, 13, 228-238. [In Ukrainian].

Popov, M. G. (1983). Filogeniia, florogenetika, sistematika. (Part 12). Kyiv: Scientific thought. [In Russian].

Prokopchuk, V. M., Tsyhanskyi, V. I., \& Tsyhanska, O. I. (2018). Vplyv stymuliatoriv rostu na vkorinennia zhyvtsiv samshytu vichnozelenoho Buxus sempervirens L. v umovakh zakrytoho gruntu. Scientific Bulletin of UNFU, 28(7), 57-59. https://doi.org/10.15421/40280712

Serebriakov, I. G. (1952). Morfologiia vegetativnykh organov vysshikh rastenii. Moscow. [In Russian].

Vulf, E. V. (1944). Istoricheskaia geografiia rastenii: Istoriia flor zemnogo shara. Moscow-Leningrad: AN SSSR, 545 p. [In Russian].

V. V. Monarkh, V. V. Kostenyuk, A. V. Korolishina

Vinnytsia National Agrarian University, Vinnytsia, Ukraine

\title{
PROSPECTS FOR THE ESTABLISHMENT OF THE ORNAMENTAL OBJECTS ON THE BASIS OF PODILLIA BOTANIC GARDEN
}

\begin{abstract}
The article describes the role and significance of Podillya Botanic Garden as a park and monument of landscape architecture of the national significance. Podillia Botanic Garden includes such divisions as arboretum, typological department of Podillya forests, pomological department (fruit and berry crops), systematic department of herbaceous plants, department of ornamental plants, nursery of decorative and wild fruit and berry crops, department of natural science and nature protection, and winter garden with a collection of subtropical plants that are unique for Podillya. In addition to the main compositional centers such as a pond, a central alley, park areas, a parterre and clearings located on the main route, Botanic Garden also includes a rosarium, a syringarium, an arboretum, research sites of the Faculty of Agronomy and Forestry, greenhouses, a fruit nursery, a biostationary, a hothouse and an exhibition site of flower-ornamental plants. The main periods of the establishment of the Botanic Garden are outlined. Botanic Garden was established according to the decision of Vinnytsia Regional Council approved on August 20, 1965 as a scientific center for the study of various issues in Botany, Plant Growing, Fruit and Vegetable Growing, Ornamental Horticulture and Floriculture. This object was founded on a voluntary basis under participation of the staff of the Pedagogical Institute, technical schools, schools, and forest organization according to the schematic plan. The taxonomic structure of the cultivated dendroflora of Botanic Garden is presented. The biomorphological and systematic structure of the cultivated dendroflora of Botanic Garden is presented. Having analyzed the species composition of the introduced plantations of Podillia Botanic Garden, it has been established that the most common introduced species of plants can be used for landscaping of squares, parks, lanes and solitaire plantings in the city of Vinnytsia.
\end{abstract}

Keywords: introduced plant; prospects; analysis; arrangement of green spaces; park and monument. 